\title{
Ameliorating effects of exercise on disrupted epididymal sperm parameters in high fat diet-induced obese rats
}

\author{
Yüksek yağlı diyetle indüklenmiş obez sıçanların bozulmuş epididimal sperm parametreleri \\ üzerine egzersizin iyileştirici etkisi
}

Merve AÇIKEL ELMAS, Serap ARBAK, Feriha ERCAN

\begin{abstract}
Objective: Obesity causes male infertility problems and affects the sperm quality. Recent studies have shown that exercise has positive effects on male fertility. The present study aimed to show the effects of swimming exercise on the epididymal sperm number, motility and morphology in hight fat diet (HFD)-induced obese
\end{abstract} rats.

Materials and Methods: Four experimental groups $(n=8$ in each group) were formed. Standard (STD) and STD+Exercise $(\mathrm{STD}+\mathrm{EXC})$ groups were fed with standard rat diet $(6 \%$ of calories as fat); HFD and HFD+Exercise (HFD+EXC) groups were fed with high fat diet ( $45 \%$ of calories as fat) for 18 weeks. The rats in STD+EXC and HFD+EXC groups were trained by swimming sessions ( $1 \mathrm{~h}$ per day for 5 days a week) during the last 6 weeks of the experiment. The left caudal epididymis was prepared to evaluate the number, motility and morphology of the spermatozoa. The right epididymal samples were processed for histological evaluation.

Results: Normospermic parameters were seen in STD and STD+EXC groups. Sperm number and motility decreased and spermatozoa with abnormal morphology increased significantly in HFD group when compared with STD group. A large number of spermatozoa in the epididymal duct lumen and regular morphology of the fibromuscular connective tissue were observed in STD and STD+EXC groups. Most of the epididymal ducts consisted of decreased amount of spermatozoal accumulation in the HFD group. Degenerated pseudostratified columnar epithelium with vacuole formation were additional findings in this group. On the other hand, swimming exercise had an enhancement effect on sperm parameters with prominent spermatozoal accumulation in the ducts of epididymis in HFD induced obese rats.

Conclusion: This study shows that HFD-induced obesity decreased the number and motility of spermatozoa, increased

Merve Açıkel Elmas. Feriha Ercan( $₫)$

Department of Histology and Embryology, School of Medicine, Marmara University, Maltepe, Istanbul, Turkey

e-mail:eferiha@hotmail.com

Serap Arbak

Department of Histology and Embryology, School of Medicine, Acrbadem Mehmet Ali Aydinlar University, Ataşehir, Istanbul, Turkey

Submitted / Gönderilme: 14.09.2018

Accepted/Kabul: 30.10 .2018 abnormal spermatozoa and caused disrupted epididymal morphology. We hypothesize that exercise enhanced HFD-induced spermatogenic and epididymal damages by the regulation of scrotal heat and possible inhibition of oxidative damage in the epididymis.

Keywords: High fat diet, Exercise, Sperm parameters

\section{ÖZ}

Amaç: Obezite erkek infertilite problemlerine neden olur ve sperm kalitesini etkiler. Egzersizin erkek fertilitesi üzerine olumlu etkileri olduğu çeşitli çalışmalar ile gösterilmiştir. Bu çalışmanın amac1, yüksek yağlı diyetle (YYD) indüklenmiş obez sıçanlarda yüzme egzersizinin epididimal sperm sayıs1, motilitesi ve epididimis morfolojisi üzerine etkilerini göstermektir.

Gereçler ve Yöntemler: $\mathrm{Bu}$ çalışmada dört deney grubu (her grupta $n=8$ ) oluşturuldu. Standart (STD) ve STD+Egzersiz (STD+EGZ) gruplarındaki sıçanlar standart sıçan diyeti ile (kalorisinde \%6 yağ içeren); YYD ve YYD+Egzersiz (YYD+EGZ) grubundaki sıçanlar da yüksek yağlı diyet ile (kalorisinde \%45 yağ içeren) 18 hafta beslendiler. STD+EGZ ve YYD+EGZ grubundaki sıçanlara deneyin son 6 haftasında haftada 5 gün, günde 1 saat yüzme egzersizi yaptırıldı. Deney sonunda sol kaudal epididimis sperm sayısı, motilitesi ve morfolojisinin incelenmesi için hazırlandı. Sağ epididimis dokusu da histolojik inceleme için hazırland.

Bulgular: STD ve STD+EGZ gruplarında normospermik parametreler gözlendi. STD grubu ile kıyaslandığında YYD grubunda sperm sayısı ve motilitesinin anlamlı olarak azaldığ 1 ve morfolojik anomaliye sahip sperm sayısının arttığı gözlendi. STD ve STD+EGZ gruplarında epididimal kanal spermatozoa ile doluydu ve fibromusküler bağ dokusu düzenli morfolojide gözlendi. YYD grubunda epididimal kanalların çoğu azalmış sayıda spermatozoa kümesinden oluşuyordu. Ayrıca, epididimisin stereosilyalı yalancı çok katlı silindirik epitelinde yer yer vakuol oluşumları gözlendi. Egzersizin ise YYD ile indüklenmiş obez siçanlarda sperm parametrelerini ve epididimis kanalındaki sperm kümesini arttırdığı gözlendi.

Sonuç: Bu çalışma, obezitenin sperm sayısını ve motilitesini azalttığını, anomalili sperm sayısını arttırdığını ve epididimis morfolojisini bozduğunu göstermektedir. Egzersizin ise, skrotal 1s1y1 dengeleyerek ve epididimisteki olas1 oksidan hasarı engelleyerek YYD ile indüklenmiş spermatogenik ve epididimal hasarı iyileştirdiği düşünülmektedir.

Anahtar kelimeler: Yüksek yağlı diyet, Egzersiz, Sperm parametreleri 


\section{Introduction}

Obesity is an important health problem that is defined as having a body mass index (BMI) greater than $30 \mathrm{~kg} / \mathrm{m}^{2}$, causing type 2 diabetes, cardiovascular diseases, endocrine and respiratory disorders, immunodeficiency, various types of cancer, psychological problems and infertility in both sexes [1]. Even only paternally-induced obesity leads couples to consult assisted reproductive techniques. Recent studies showed that probable effects of paternal obesity in the formation of newborns were prone to chronic diseases such as obesity and diabetes $[2,3]$.

Obesity changes sperm morphology, motility and function, causing deterioration of testis structure [4]. In recent years, it has been shown that obesity reduces fertility and affects embryonic health $[3,5]$. According to studies in obese animal models, high fat diet (HFD) had a decreasing effect on sperm capacitation and sperm binding ability when compared to control diet $[4,6]$. Furthermore, feeding with HFD caused impaired morphology of sperms and decreased levels of testosterone and sperm motility $[2,4,6,7]$.

The spermatogenesis process is very sensitive to temperature. The optimal temperature is $34-35^{\circ} \mathrm{C}$ in humans $[4,8,9]$. Increased testicular temperature leads to a decrease in sperm motility and an increase in sperm DNA damage $[10,11]$. Obesity increases scrotal temperature thus changes sperm production by increasing gonadal temperature [12]. Epididymal cells produce different proteins, glycoproteins, glycolipids and phospholipids which are released in the lumen, necessary for maturation and survival of sperms [13]. In obese males, a large amount of fat deposited in the scrotum may be a relevant cause for the formation of oxidative stress [14] and alters epididymal morphology and function. This situation can also cause the alteration of sperm parameters which are stored in the epididymal lumen.

Diet and exercise can prevent or even reverse the effects of obesity-induced damage on sperm function [4]. Experimental studies showed that diet and exercise ameliorated sperm parameters such as motility, morphology, and sperm DNA damage and increased both fertilization and development of blastocyst [2,15-17]. The aim of this study is to investigate the effects of swimming exercise both on epididymal morphology and epididymal sperm parameters such as sperm number, motility and morphology in HFD induced obese rats.

\section{Material and Methods}

\section{Animals}

Sprague Dawley albino male rats (7 weeks old, 250-300 gr) taken from the Experimental Animal Implementation and Research Centre of Acrbadem University were used in this study. The experimental study was approved by Acrbadem University, Animal Care and Ethical Committee for Experimental Animals (2018-36).

\section{Experimental Design}

The rats were maintained at $22 \pm 2{ }^{\circ} \mathrm{C}$ during the experimental period in a laboratory environment with a standard light/dark (12/12 h) cycle. Four experimental groups ( $\mathrm{n}=8$ in each group) were formed for the study. Standard (STD) and STD+Exercise (STD+EXC) groups were fed with standard rat diet $(6 \%$ of calories as fat). HFD and HFD+Exercise (HFD+EXC) groups were fed with high fat diet ( $45 \%$ of calories as fat) for 18 weeks $[18,19]$. The animals in STD+EXC and HFD+EXC groups were trained by daily swimming sessions for $1 \mathrm{~h}$ per day for 5 days/week in the last 6 weeks of the experimental period. At the end of the experimental procedure, animals were fasted for 6 $\mathrm{h}$, weighted and then anesthetized by intraperitoneal injection of ketamine $(0.9 \mathrm{cc} / \mathrm{kg})$ and xylazine $(0.7 \mathrm{cc} /$ $\mathrm{kg}$ ). Epididymis of left testis was removed for sperm analysis, and the epididymal samples of the right testis were obtained for histological analyses.

\section{Histological Preparation}

\section{Sperm counting, motility rate and morphological evaluation}

Left caudal epididymis were dissected and cut into the small pieces in all groups, then epididymal samples were placed in $5 \mathrm{ml}$ Earle's Balanced Salts Solution (Sigma, USA). Following centrifugation, supernatant was removed. Routine density gradient method was applied for sperm evaluation. Following the removal of the supernatant, the pellet was diluted with $2 \mathrm{ml}$ sperm washing medium (SAGE, UK) and centrifuged at 2000 $\mathrm{rpm}$ for $10 \mathrm{~min}$. Then, supernatant was seperated and pellet was diluted with $0.3 \mathrm{ml}$ fertilization medium (SAGE, UK). Sperm counting and motility rate were analyzed from one drop of pellet sample and examined by using Macler Counting Chamber (Sefi Medical Instruments, Haifa, 
Israel) at photomicroscope. Smear samples were fixed and dehydrated with $96 \%$ ethanol and stained with DiffQuick kit (Medion Diagnostics, Grafelfing, Germany) for the morphological evaluation. One hundred spermatozoa were evaluated for head, neck and tail morphology of the spermatozoa under 100x immersion oil objective of the photomicroscope.

\section{Light Microscopical Preparation}

Right caudal epididymal samples were fixed for 72 hours with $10 \%$ neutral buffered formalin solution. After fixation, tissues were dehydrated through ascending alcohol series $(70 \%, 90 \%, 96 \%, 100 \%)$ and cleared with xylene. Then, tissue samples were embedded in paraffin. Sections of approximately $5 \mu \mathrm{m}$ of thickness were stained with hematoxylin and eosin (H\&E).

All of the histological slides were examined and photographed with a digital camera (Olympus C-5060, Tokyo, Japan) attached to a photomicroscope (Olympus BX51, Tokyo, Japan).

\section{Statistical Analysis}

Data were analysed by using one-way analysis of variance (ANOVA). Differences between groups were determined with Tukey's multiple comparisons test. Significance of differences was taken at the level of $\mathrm{P}<0.05$. Calculations were done using Prism 6.0 (GraphPad Software, San Diego, CA, USA).

\section{Results}

The total body weight measurements revealed that rats of HFD and HFD+EXC groups $(315.8 \pm 12.73,319.6 \pm$ 10.83 respectively) were heavier than the rats of STD and STD+EXC group (303.6 $\pm 9.48,306.0 \pm 9.66$ respectively). Compared with the STD group, a significant increase in rat weight was observed in the HFD $(\mathrm{P}<0.05)$ and HFD+EXC $(\mathrm{P}<0.01)$ groups.
The number of spermatozoa in HFD $(\mathrm{P}<0.001)$ and HFD+EXC $(\mathrm{P}<0.01)$ groups were significantly reduced compared to the STD group. Moreover, the number of spermatozoa were increased in the HFD+EXC group $(\mathrm{P}<$ 0.01) compared to the HFD group (Figure 1A).

The progressive motile spermatozoa were significantly reduced in the HFD group $(\mathrm{P}<0.001)$ compared to the STD group, while progressive spermatozoa were significantly increased in the HFD+EXC group $(\mathrm{P}<0.001)$ compared to the HFD group (Figure 1B).

A)

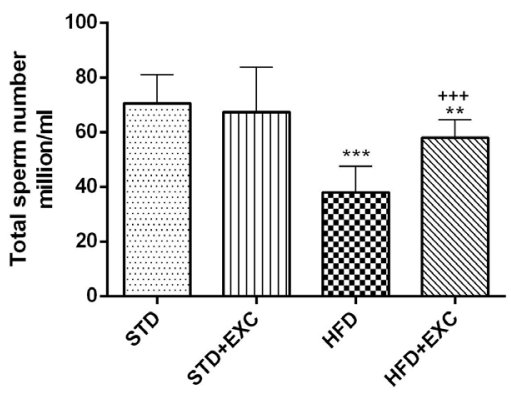

B)

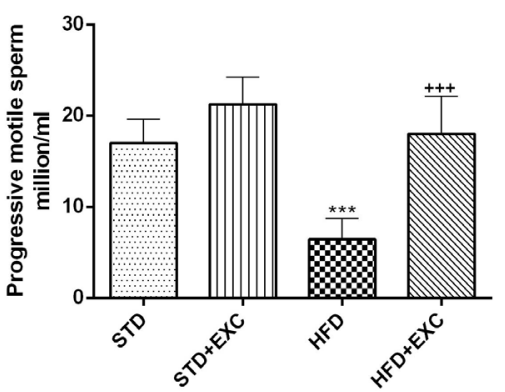

C)

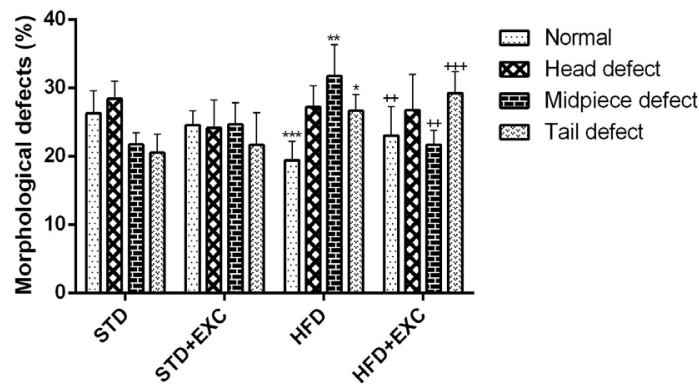

Figure 1. Evaluation of sperm count (A), sperm motility (B) and morphological defects $(\mathrm{C})$, in the experimental groups. ${ }^{*} \mathrm{P}<0.05,{ }^{*} \mathrm{P}<$ $0.01,{ }^{* * *} \mathrm{P}<0.001$ compared to STD group $;{ }^{+} \mathrm{P}<0.01,{ }^{++} \mathrm{P}<0.001$ compared to HFD group. 


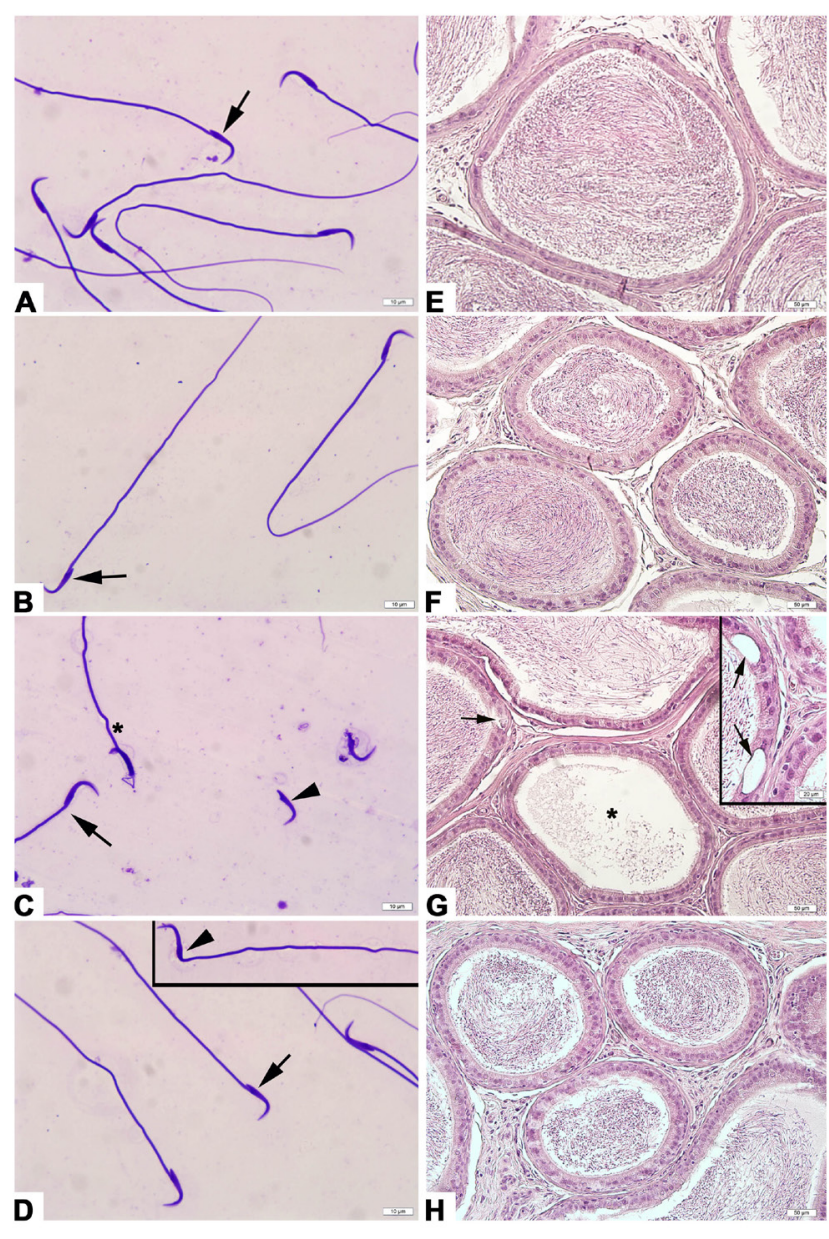

Figure 2. Representative light micrographs of experimental groups. Normal spermatozoa (arrow) and abnormal spermatozoa with mix $\left(^{*}\right)$ and neck (arrowhead) defects are seen in STD (A), STD+EXC (B), HFD (C) and HFD+EXC (D) groups. Regular epididymal duct morphology with accumulation of spermatozoa in luminal region of STD (E) and STD+ EXC (F) groups; decrease of sperm accumulation $(*)$, epithelial degeneration with large vaculoles (arrow) in HFD group (G); quite regular epididymal ducts with sperm accumulation in HFD+EXC group $(\mathrm{H})$ are seen in epididymis. A-D: Diff-Quick staining, E-H: H\&E staining. Scale bar: A - D: $10 \mu \mathrm{m}$; E-H: $50 \mu \mathrm{m}$, inset: $20 \mu \mathrm{m}$.

The spermatozoa with normal morphology and abnormal spermatozoa presenting head, midpiece and tail defects were observed in STD and STD+EXC groups. However, normal spermatozoa $(\mathrm{P}<0.001)$ were significantly decreased and abnormal spermatoza with midpiece $(\mathrm{P}<0.01)$ and tail $(\mathrm{P}<0.05)$ defects were significantly increased in the HFD group compared to STD group. Additionally, normal spermatozoa $(\mathrm{P}<0.01)$ were significantly increased and abnormal spermatozoa with midpiece $(\mathrm{P}<0.01)$ and tail $(\mathrm{P}<0.01)$ defects were significantly decreased in the HFD+EXC group compared to the HFD group (Figure 1C and 2A-D).
Normal epididymal duct morphology, all together with luminal area, large numbers of spermatozoal accumulation were noticed in STD and STD+EXC groups. Decreased level of spermatozoal accumulation, immature spermatozoa in the luminal area, degenaration of sterociliated pseudostratified columnar epithelium with large vacuoles were observed in the HFD group. These morphological alterations were ameliorated in the HFD+EXC group (Figure $2 \mathrm{E}-\mathrm{H}$ ).

\section{Discussion}

The present study reveals that HFD-induced obesity decreases the number, and motility of spermatozoa, and increases the incidence of degenerated spermatozoa. Furthermore, HFD disrupts the epididymal duct morphology. Moderate swimming exercise has been found to ameliorate HFD-induced sperm parameters and epididymal damages.

Body mass index is one of the important factors affecting fertility. As, BMI increases, the rate of infertility in men increases 3-fold [20]. Individuals with a BMI greater than $25 \mathrm{~kg} / \mathrm{m}^{2}$ have a lower total sperm count than those of normal weight, and the measured volume of ejaculate is decreased steadily with an increase in BMI [21].

Obesity results in harmful effects on the sperm parameters in males $[15,16]$. Similar adverse effects are also shown in rodent obesity models [22,23]. Obesity changes the environment crucial for spermatogenesis in testis and has an adverse effect on the sperm maturation in epididymis. Obesity impairs the physical and molecular structure of sperm during spermatogenesis and has an adverse effect on sperm maturation in epididymis. As a result, decreased sperm quality is associated with an increased risk in male infertility [24].

Hyperinsulinemia and hyperglycaemia, seen in obesity models of rats $[2,7,25]$, change the number of sperm, impair sperm quality and cause decrease in fertility [26,27]. In addition, low testosterone level may cause clinical metabolic syndrome formation and so obesity may be a symptom of low testosterone level, although not directly causes low sperm count [28-30].

Obesity leads to an increase in adipocyte number/ size and causes both physical and hormonal changes [24]. Physical changes cause an increase in scrotal temperature [12], On the other hand, hormonal changes might induce decrease of testosterone level [6]. These changes result in 
oligozoospermia and azoospermia [31], a decrease in semen volume and contribute to obesity-related male infertility [32].

Diet and/or exercise interventions enhance basic sperm parameters such as motility and morphology in obese males. Limited number of studies showed the reversibility of the harmful effects of obesity [4]. Exercise increases sperm motility and morphology, reduces sperm DNA and oxidative damages [4]. Our study showed the ameliorating effects of exercise on sperm count, motility and morphology in HFD induced obese rats. This might be due to inhibition of oxidative and DNA damages in epididymal spermatozoa. Studies on obese mice have shown that exercise enhanced impaired sperm physiology [4]. An experimental study showed that FSH, LH, testosterone levels and semen quality increased in physically active individuals when compared to sedentary people [33]. Yet, in another study it has been shown that the semen parameters deteriorate in long-term heavy cycling people [34]. Although, moderate exercise increases testosterone/estrogen ratio and sperm quality, high-intensity exercise might have a negative or nonsignificant effect. Moderate swimming exercise enhanced sperm parameters in HFD-induced obese rats in this study. It can be concluded that the effects of exercise on the reproductive function of obese male rats might be related to the duration and intensity of exercise.

Testicular spermatozoa have no progressive motility and cannot fertilize oocytes, yet they acquire fertilization ability when they reach epididymis [13]. Therefore, epididymal tissue morphology and function are important for maturation of spermatozoa. For this reason, morphological and functional changes in the epididymis of obese animals may also change spermatozoal maturation. A large amount of adipose tissue accumulated in obese rats, probably causes oxidative stress in the epididymis [13]. In this study, it was observed that, epididymal ducts had degenerated epididymal epithelium with decreased amount of luminal sperm accumulation and increased immature spermatozoa in HFD-induced obese rats. Also, it was observed that sperm motility was reduced in this group. This data could be related with the altered epididymal secretion which has a role for acquiring sperm motility. Swimming exercise enhanced sperm motility in HFD-induced obese rats.

In conclusion, HFD-induced obesity in rats reduced the sperm number and progressive motility, increased the number of abnormal spermatozoa. Additionally, epididymal morphology was distrupted in this group which has a role for the maturation of spermatozoa. Swimming exercise amelioriated sperm parameters and epididymal morphology by the regulation of scrotal heat and possible inhibition of oxidative damage in the epididymis.

\section{Acknowledgement}

This study was financially supported by the Marmara University, Scientific Research Project Commission and Research Fund (SAG-C-DRP-131016-0443). The authors would like to thank M Kutay Köroğlu, MSc for his technical support for the sperm parameters processing.

\section{References}

1. Roumaud P, Martin LJ. Roles of leptin, adiponectin and resistin in the transcriptional regulation of steroidogenic genes contributing to decreased Leydig cells function in obesity. Horm Mol Biol Clin Investig 2015;24:25-45. doi: 10.1515/hmbci-2015-0046.

2. Palmer NO, Bakos HW, Fullston T, Lane M. Impact of obesity on male fertility, sperm function and molecular composition. Spermatogenesis 2012;2:253-63. doi: 10.4161/spmg.21362.

3. Ramlau-Hansen CH, Hansen M, Jensen CR, Olsen J, Bonde JP, Thulstrup AM. Semen quality and reproductive hormones according to birthweight and body mass index in childhood and adult life: two decades of follow-up. Fertil Steril 2010;94:610-8. doi: 10.1016/j.fertnstert.2009.01.142.

4. Palmer NO, Bakos HW, Owens JA, Setchell BP, Lane M. Diet and exercise in an obese mouse fed a high-fat diet improve metabolic health and reverse perturbed sperm function. Am J Physiol Endocrinol Metab 2012;302:E768-80. doi: 10.1152/ ajpendo.00401.2011.

5. Nguyen RH, Wilcox AJ, Skjaerven R, Baird DD. Men's body mass index and infertility. Hum Reprod 2007;22:2488-93. doi: 10.1093/humrep/dem139.

6. Fan Y, Liu Y, Xue K, et al. Diet-induced obesity in male C57BL/6 mice decreases fertility as a consequence of disrupted blood-testis barrier. PLoS One 2015;10:e0120775. doi: 10.1371/journal.pone.0120775.

7. Ghanayem BI, Bai R, Kissling GE, Travlos G, Hoffler U. Diet-induced obesity in male mice is associated with reduced fertility and potentiation of acrylamide-induced reproductive toxicity. Biol Reprod 2010;82:96-104. doi: 10.1095/ biolreprod.109.078915.

8. Bedford JM. Human spermatozoa and temperature: the elephant in the room. Biol Reprod 2015;93:97. doi: 10.1095/ biolreprod.115.130658.

9. Robinson D, Rock J, Menkin MF. Control of human spermatogenesis by induced changes of intrascrotal temperature. JAMA 1968;204:290-7.

10. Paul C, Melton DW, Saunders PT. Do heat stress and deficits in DNA repair pathways have a negative impact on male fertility? Mol Hum Reprod 2008;14:1-8. doi: 10.1093/ molehr/gam089. 
11. Shiraishi K, Takihara H, Matsuyama H. Elevated scrotal temperature, but not varicocele grade, reflects testicular oxidative stress-mediated apoptosis. World J Urol 2010;28:359-64. doi: 10.1007/s00345.009.0462-5.

12. Garolla A, Torino M, Miola P, et al. Twenty-four-hour monitoring of scrotal temperature in obese men and men with a varicocele as a mirror of spermatogenic function. Hum Reprod 2015;30:1006-13. doi: 10.1093/humrep/dev057.

13. Vigueras-Villasenor RM, Rojas-Castaneda JC, ChavezSaldana $M$, et al. Alterations in the spermatic function generated by obesity in rats. Acta Histochem 2011;113:21420. doi: 10.1016/j.acthis.2009.10.004.

14. Dandona P, Aljada A, Chaudhuri A, Mohanty P, Garg R. Metabolic syndrome: a comprehensive perspective based on interactions between obesity, diabetes, and inflammation. Circulation 2005;111:1448-54. doi: 10.1161/01. CIR.000.015.8483.13093.9D.

15. Du Plessis SS, Cabler S, McAlister DA, Sabanegh E, Agarwal A. The effect of obesity on sperm disorders and male infertility. Nat Rev Urol 2010;7:153-61. doi: 10.1038/ nrurol.2010.6.

16. Hammoud AO, Wilde N, Gibson M, Parks A, Carrell DT, Meikle AW. Male obesity and alteration in sperm parameters. Fertil Steril 2008;90:2222-5. doi: 10.1016/j. fertnstert.2007.10.011.

17. MacDonald AA, Herbison GP, Showell M, Farquhar CM. The impact of body mass index on semen parameters and reproductive hormones in human males: a systematic review with meta-analysis. Hum Reprod Update 2010;16:293-311. doi: 10.1093/humupd/dmp047.

18. Atilgan D, Parlaktas BS, Uluocak N, et al. Weight loss and melatonin reduce obesity-induced oxidative damage in rat testis. Adv Urol 2013;2013:836121. doi: $10.1155 / 2013 / 836121$.

19. Ickin Gulen M, Guven Bagla A, Yavuz O, Hismiogullari AA. Histopathological changes in rat pancreas and skeletal muscle associated with high fat diet induced insulin resistance. Biotech Histochem 2015;90:495-505. doi: 10.3109/10520.295.2015.1021380.

20. Sallmen M, Sandler DP, Hoppin JA, Blair A, Baird DD. Reduced fertility among overweight and obese men. Epidemiology 2006;17:520-3. doi: 10.1097/01. ede.000.022.9953.76862.e5.

21. Chavarro JE, Toth TL, Wright DL, Meeker JD, Hauser R. Body mass index in relation to semen quality, sperm DNA integrity, and serum reproductive hormone levels among men attending an infertility clinic. Fertil Steril 2010;93:2222-31. doi: 10.1016/j.fertnstert.2009.01.100.

22. Bakos HW, Mitchell M, Setchell BP, Lane M. The effect of paternal diet-induced obesity on sperm function and fertilization in a mouse model. Int $\mathrm{J}$ Androl 2011;34(5 Pt 1):402-10. doi: 10.1111/j.1365-2605.2010.01092.x.

23. Fernandez CD, Bellentani FF, Fernandes GS, et al. Dietinduced obesity in rats leads to a decrease in sperm motility. Reprod Biol Endocrinol 2011;9:32. doi: 10.1186/1477-78279-32.

24. Liu Y, Ding Z. Obesity, a serious etiologic factor for male subfertility in modern society. Reproduction 2017;154:R123-R31. doi: 10.1530/REP-17-0161.

25. Ng SF, Lin RC, Laybutt DR, Barres R, Owens JA, Morris MJ. Chronic high-fat diet in fathers programs beta-cell dysfunction in female rat offspring. Nature 2010;467(7318):963-6. doi: 10.1038/nature09491.

26. Kasturi SS, Tannir J, Brannigan RE. The metabolic syndrome and male infertility. J Androl 2008;29:251-9. doi: 10.2164/ jandrol.107.003731.

27. La Vignera S, Condorelli RA, Vicari E, Calogero AE. Negative effect of increased body weight on sperm conventional and nonconventional flow cytometric sperm parameters. J Androl 2012;33:53-8. doi: 10.2164/jandrol.110.012120.

28. Akishita M, Fukai S, Hashimoto M, et al. Association of low testosterone with metabolic syndrome and its components in middle-aged Japanese men. Hypertens Res 2010;33:587-91. doi: 10.1038/hr.2010.43.

29. Haring R, Volzke H, Felix SB, et al. Prediction of metabolic syndrome by low serum testosterone levels in men: results from the study of health in Pomerania. Diabetes 2009;58:2027-31. doi: 10.2337/db09-0031.

30. Kupelian V, Page ST, Araujo AB, Travison TG, Bremner WJ, McKinlay JB. Low sex hormone-binding globulin, total testosterone, and symptomatic androgen deficiency are associated with development of the metabolic syndrome in nonobese men. J Clin Endocrinol Metab 2006;91:843-50. doi: 10.1210/jc.2005-1326.

31. Sermondade N, Faure C, Fezeu L, Levy R, Czernichow S, Obesity-Fertility Collaborative G. Obesity and increased risk for oligozoospermia and azoospermia. Arch Intern Med 2012;172:440-2. doi: 10.1001/archinternmed.2011.1382.

32. Shayeb AG, Harrild K, Mathers E, Bhattacharya S. An exploration of the association between male body mass index and semen quality. Reprod Biomed Online 2011;23:717-23. doi: 10.1016/j.rbmo.2011.07.018.

33. Vaamonde D, Da Silva-Grigoletto ME, Garcia-Manso JM, Barrera N, Vaamonde-Lemos R. Physically active men show better semen parameters and hormone values than sedentary men. Eur J Appl Physiol 2012;112:3267-73. doi: 10.1007/ s00421.011.2304-6.

34. Hajizadeh Maleki B, Tartibian B. Long-term low-to-intensive cycling training: Impact on semen parameters and seminal cytokines. Clin J Sport Med 2015;25:535-40. doi: 10.1097/ JSM.000.000.0000000122. 